\title{
The study of production management experiment teaching system formation for Economic management specialty/major in university
}

\author{
Wen Ming $\mathrm{Han}^{1, \mathrm{a}}$, Tong Tong Zhang ${ }^{1, \mathrm{~b}}$, Jun $\mathrm{Wu}^{1, \mathrm{c}}$ and Jin Yan $\mathrm{Li}^{1, \mathrm{~d}}$ \\ ${ }^{1}$ School of Economics and Management, Jiangsu University Of Science and Technology, Zhenjiang, \\ Jiangsu, 212003, China \\ awlmh63@163.com, bzhangtongtong1989@163.com, c wujunjm@sina.com, ${ }^{\mathrm{d}}$ lijinyan20@126.com
}

Keywords: experimental teaching; production management; the experimental system; economy management talents training

\begin{abstract}
This paper analyzes the economic management category talents cultivation problem of colleges and universities in China, expounds the necessity and urgency of cultivate students' practical ability and innovation ability, sets the production management as an object, puts forward the basic train of thought for production management experimental teaching system, condenses the typical problem of production management in four dimensions. This paper discusses contents, principles of experiment teaching system for production management and functions which should be able to reflected in production management experiment projects, this work provides guidance and reference significance to construction and operation production management experiment system for colleges and universities.
\end{abstract}

\section{Introduction}

With the strengthening of social economy development and competition, society puts forward higher request to economic management class students' knowledge structure, practical ability and comprehensive quality, especially students are required to have strong ability of combination theory with practice, application of learned knowledge. As one of the core curriculum of economic management major — - production operation management is a course which theory and practice combined closely, but in the traditional classroom teaching mode, students' hands-on skills are very poor, and because of a lack of practical experience, it's difficult to really understand the related theory knowledge and digest after finished school study. Also, it's difficult to quickly adapt to fast-paced, various actual job when get into social life for students. Traditionally, the main link students contact with actual_ cognition practice, especially in professional practice, it's unsustainable to continue the past practices. Because of relatively numerous of students, professional internship positions that companies can provide is limited. And based on the consideration of protecting commercial secrets, it is hard to contact with the internship substantial business for students. Therefore, the reform of the traditional teaching mode has become an important subject faced by class teaching.

FUNG Y.(2010)discussed the relationship between the university laboratory and training the innovative talents, university laboratory building and opening up and the function of the laboratory in cultivating talents. Stefanovic M.(2013) thought the concept of laboratories for distance (e-learning) with remotely controlled laboratory set-ups or virtual laboratories with different simulations have an important role in industrial engineering education and training. Jiang Nanyun(2013) proposed the guidance problem (PBL), made students to apply the knowledge what they have learned of manufacturing operation management to solve work site layout, production site management, virtual reality simulation and production plan formulation practical problems etc. Jiang zengqiang(2013) put forward the thought of establish the relationship between experimental courses on the basis of hardware devices, MES as the main line and simulate the actual production site. Develop the industrial integration of engineering experiment. Fan Shuhai (2011) proposed an affordable VR - 3 d reconstruction scheme for industrial engineering laboratory, selected hardware and software of each links, and described working process of the system. Zhen Yuqiao(2013) put a typical mechanical and electrical product as the research object, carried out trainings as product manufacturing organization 
and management, product manufacturing process analysis and optimization, manufacturing system modeling simulation and optimization etc. In this article, the author thinks that it need to be set off from school talents cultivation orientation, typical the production operation management problems, reproduced tasks, processes, and work methods of enterprise production and operation environment in a laboratory environment, increase the intensity of experimental and practice teaching, training student's practical ability and innovation ability. In this paper, manufacturing management oriented talent cultivation as an example, discussed the construction of experiment teaching system for production management.

\section{Contents and principles of the production management experiment teaching system}

\section{Formation goals of production management experiment teaching system.}

The built production management of experiment teaching system should be able to achieve the following goals:

(1) By systematic analysis of the complicated production management problems, refining out the typical problems as a research subject of experimental system building and the experimental project design .

(2) Fully functional. Cover the entire content from management ideas to management methods of the enterprise production management.

(3) To provide experiment system for training students the ability of solving problems of enterprise production management, can be widely support undergraduate and graduate students the need of basic type, elevated and innovative experimental project study, and provide experiment platform for teachers' scientific research work.

\section{Contents of the experiment teaching system for production management}

(1) Investigate enterprise production management problems in four dimensions as "the characteristics of responsibilities division”, "the driving mode of production logistics", "production management hierarchy", "planning and scheduling method", summarized into 36 kinds of typical functional forms for production management work. Design and analysis various typical problems from the basic characteristics, operation basement and condition, main problems, improve directions respectively.

Table1. Typical functional forms for the production management

\begin{tabular}{|c|c|c|c|c|c|c|c|c|c|c|}
\hline \multirow[t]{2}{*}{ No } & \multicolumn{2}{|c|}{$\begin{array}{l}\text { Dimension1: } \\
\text { responsibilitie } \\
\text { s division }\end{array}$} & \multicolumn{3}{|c|}{$\begin{array}{l}\text { Dimension 2: } \\
\text { driving mode of } \\
\text { production logistics }\end{array}$} & \multicolumn{3}{|c|}{$\begin{array}{c}\text { Dimension 3: } \\
\text { production } \\
\text { management hierarchy }\end{array}$} & \multicolumn{2}{|c|}{$\begin{array}{c}\text { Dimension 4: } \\
\text { planning and } \\
\text { scheduling method }\end{array}$} \\
\hline & $\begin{array}{l}\text { Centralis } \\
\text {-ation }\end{array}$ & $\begin{array}{l}\text { Decentr- } \\
\text { alization }\end{array}$ & Push & Pull & $\underset{\text { combination }}{\text { push-pull }}$ & $\begin{array}{l}\text { Corporat } \\
\text { e level }\end{array}$ & $\begin{array}{l}\text { Worksh } \\
\text {-op level }\end{array}$ & $\begin{array}{l}\text { Team } \\
\text { level }\end{array}$ & $\begin{array}{c}\text { Criteria } \\
\text { based }\end{array}$ & $\begin{array}{l}\text { Optimization } \\
\text { algorithm based }\end{array}$ \\
\hline 1 & $\sqrt{ }$ & & $\sqrt{ }$ & & & $\sqrt{ }$ & & & $\sqrt{ }$ & \\
\hline 2 & $\sqrt{ }$ & & & $\sqrt{ }$ & & $\sqrt{ }$ & & & $\sqrt{ }$ & \\
\hline 3 & $\sqrt{ }$ & & & & $\sqrt{ }$ & $\sqrt{ }$ & & & $\sqrt{ }$ & \\
\hline 4 & $\sqrt{ }$ & & $\sqrt{ }$ & & & & $\sqrt{ }$ & & $\sqrt{ }$ & \\
\hline 5 & $\sqrt{ }$ & & & $\sqrt{ }$ & & & $\sqrt{ }$ & & $\sqrt{ }$ & \\
\hline 6 & $\sqrt{ }$ & & & & $\sqrt{ }$ & & $\checkmark$ & & $\sqrt{ }$ & \\
\hline 7 & $\sqrt{ }$ & & $\sqrt{ }$ & & & & & $\sqrt{ }$ & $\sqrt{ }$ & \\
\hline 8 & $\sqrt{ }$ & & & $\sqrt{ }$ & & & & $\sqrt{ }$ & $\sqrt{ }$ & \\
\hline 9 & $\sqrt{ }$ & & & & $\sqrt{ }$ & & & $\sqrt{ }$ & $\sqrt{ }$ & \\
\hline 10 & $\sqrt{ }$ & & $\sqrt{ }$ & & & $\sqrt{ }$ & & & & $\sqrt{ }$ \\
\hline 11 & $\sqrt{ }$ & & & $\sqrt{ }$ & & $\sqrt{ }$ & & & & $\sqrt{ }$ \\
\hline 12 & $\sqrt{ }$ & & & & $\sqrt{ }$ & $\sqrt{ }$ & & & & $\sqrt{ }$ \\
\hline 13 & $\sqrt{ }$ & & $\sqrt{ }$ & & & & $\sqrt{ }$ & & & $\sqrt{ }$ \\
\hline 14 & $\sqrt{ }$ & & & $\sqrt{ }$ & & & $\sqrt{ }$ & & & $\sqrt{ }$ \\
\hline 15 & $\sqrt{ }$ & & & & $\sqrt{ }$ & & $\sqrt{ }$ & & & $\sqrt{ }$ \\
\hline 16 & $\sqrt{ }$ & & $\sqrt{ }$ & & & & & $\sqrt{ }$ & & $\sqrt{ }$ \\
\hline
\end{tabular}




\begin{tabular}{|c|c|c|c|c|c|c|c|c|c|c|}
\hline 17 & $\sqrt{ }$ & & & $\sqrt{ }$ & & & & $\checkmark$ & & $\sqrt{ }$ \\
\hline 18 & $\sqrt{ }$ & & & & $\sqrt{ }$ & & & $\checkmark$ & & $\sqrt{ }$ \\
\hline 19 & & $\sqrt{ }$ & $\sqrt{ }$ & & & $\checkmark$ & & & $\sqrt{ }$ & \\
\hline 20 & & $\sqrt{ }$ & & $\sqrt{ }$ & & $\checkmark$ & & & $\sqrt{ }$ & \\
\hline 21 & & $\sqrt{ }$ & & & $\checkmark$ & $\sqrt{ }$ & & & $\sqrt{ }$ & \\
\hline 22 & & $\sqrt{ }$ & $\sqrt{ }$ & & & & $\sqrt{ }$ & & $\sqrt{ }$ & \\
\hline 23 & & $\sqrt{ }$ & & $\sqrt{ }$ & . & & $\sqrt{ }$ & & $\sqrt{ }$ & \\
\hline 24 & & $\sqrt{ }$ & & & $\sqrt{ }$ & & $\checkmark$ & & $\sqrt{ }$ & \\
\hline 25 & & $\sqrt{ }$ & $\sqrt{ }$ & & & & & $\checkmark$ & $\sqrt{ }$ & \\
\hline 26 & & $\sqrt{ }$ & & $\sqrt{ }$ & & & & $\checkmark$ & $\sqrt{ }$ & \\
\hline 27 & & $\sqrt{ }$ & & & $\sqrt{ }$ & . & & $\sqrt{ }$ & $\sqrt{ }$ & \\
\hline 28 & & $\sqrt{ }$ & $\sqrt{ }$ & & & $\sqrt{ }$ & & & & $\sqrt{ }$ \\
\hline 29 & & $\sqrt{ }$ & & $\sqrt{ }$ & & $\checkmark$ & & & & $\sqrt{ }$ \\
\hline 30 & & $\sqrt{ }$ & & & $\sqrt{ }$ & $\sqrt{ }$ & & & & $\sqrt{ }$ \\
\hline 31 & & $\sqrt{ }$ & $\sqrt{ }$ & & & & $\sqrt{ }$ & & & $\sqrt{ }$ \\
\hline 32 & & $\sqrt{ }$ & & $\sqrt{ }$ & & & $\sqrt{ }$ & & & $\sqrt{ }$ \\
\hline 33 & & $\sqrt{ }$ & & & $\sqrt{ }$ & & $\sqrt{ }$ & & & $\sqrt{ }$ \\
\hline 34 & & $\sqrt{ }$ & $\sqrt{ }$ & & . & & & $\sqrt{ }$ & & $\sqrt{ }$ \\
\hline 35 & & $\sqrt{ }$ & & $\sqrt{ }$ & & & & $\sqrt{ }$ & & $\sqrt{ }$ \\
\hline 36 & & $\sqrt{ }$ & & & $\sqrt{ }$ & & & $\checkmark$ & & $\sqrt{ }$ \\
\hline
\end{tabular}

(2) To various typical forms, according three phases,design and running — result evaluation improve the optimization of the production planning and scheduling scheme to construct experimental system, design experimental projects and contents. Making students understand and grasp enterprise production management process, work contents, and improvement method completely and systematically.

\section{The theory of experiment teaching system for production management}

The theory of experiment teaching system for production management is shown in figure 1 .

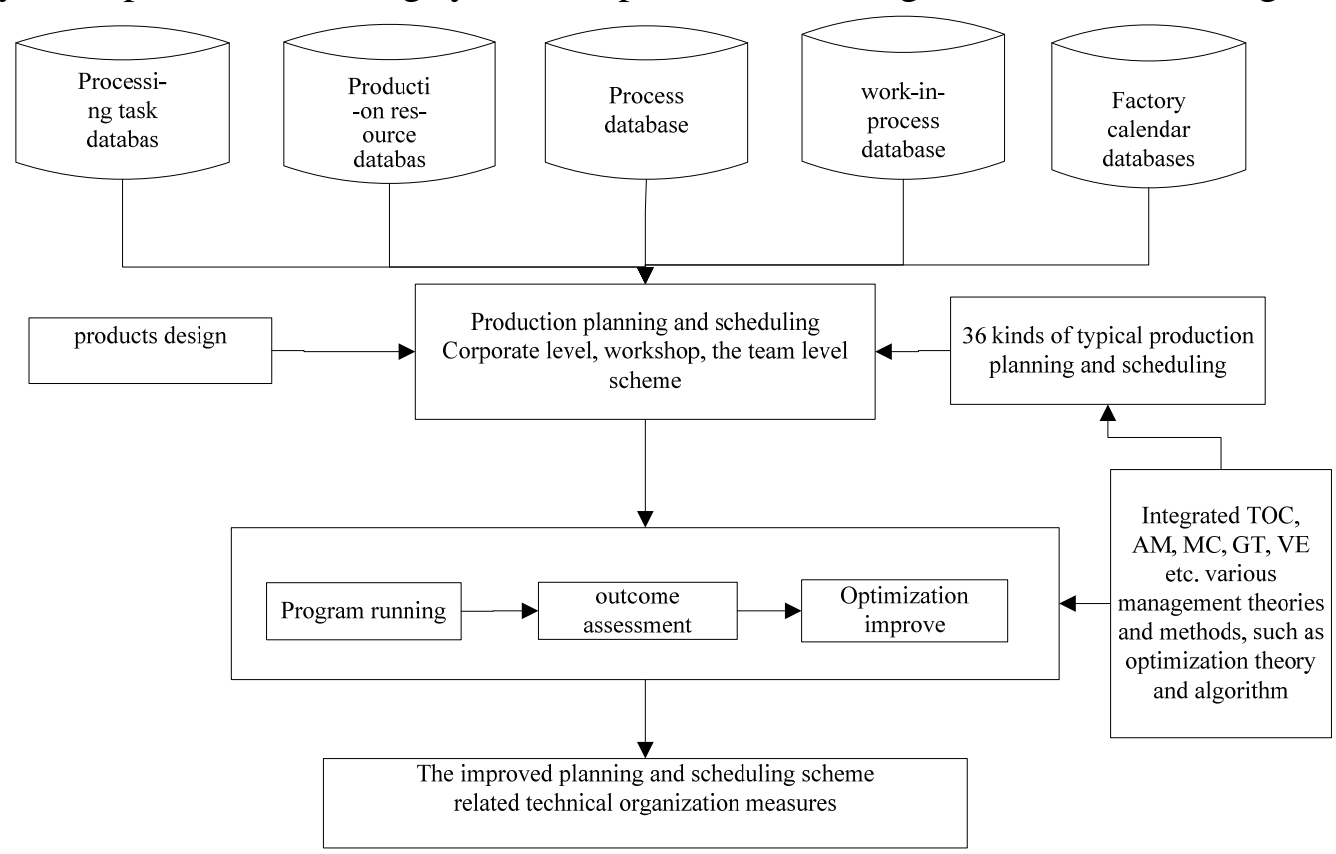

Figure1. The production management experiment system schematic diagram

\section{Functions of experiment teaching system for production management}

Function frame of the constructed production management experimental teaching system is shown in figure 2 . 


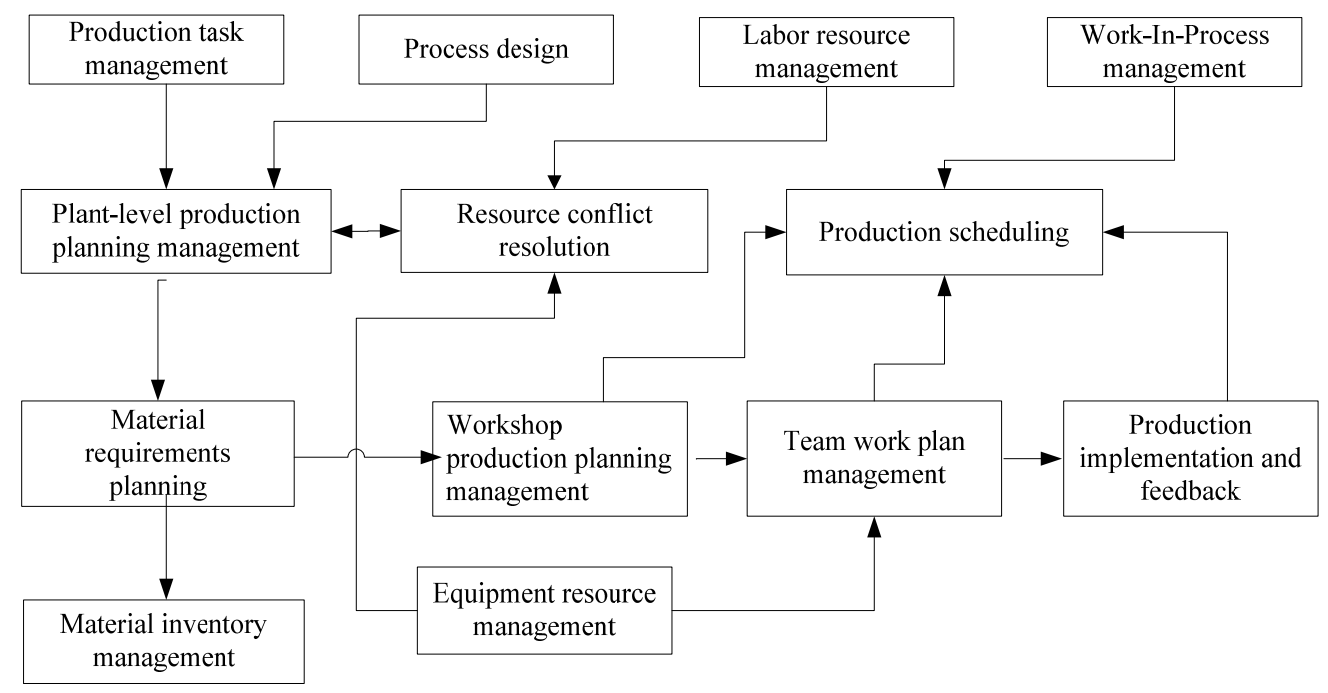

Figure 2. The production management experiment system function frame

According to the previous targets and content requirements of production management experiment system, the designed production management experimental projects should be able to reflect functions as shown in table 2.

Table 2. The main functions of the production management experiment system

\begin{tabular}{|c|c|c|}
\hline System name & Function name & Functional specifications \\
\hline \multirow{2}{*}{$\begin{array}{l}\text { Production task } \\
\text { management }\end{array}$} & $\begin{array}{l}\text { Establish and maintain } \\
\text { production tasks }\end{array}$ & $\begin{array}{l}\text { Form production tasks according to orders and sales forecast, and } \\
\text { set the priority for production tasks according to the state of } \\
\text { emergency }\end{array}$ \\
\hline & Engineering information & Form engineering informations according to production tasks \\
\hline \multirow{2}{*}{$\begin{array}{l}\text { Process scheme } \\
\text { management }\end{array}$} & $\begin{array}{l}\text { Product structure } \\
\text { maintenance }\end{array}$ & $\begin{array}{l}\text { Form relations between materials in product design drawings by } \\
\text { product structure maintenance }\end{array}$ \\
\hline & Process scheme maintenance & $\begin{array}{l}\text { Design process schemes according to production tasks and } \\
\text { preparation processing products }\end{array}$ \\
\hline \multirow{4}{*}{$\begin{array}{l}\text { Corporate level } \\
\text { production } \\
\text { planning } \\
\text { management }\end{array}$} & $\begin{array}{l}\text { Corporate level preliminary } \\
\text { production planning }\end{array}$ & $\begin{array}{c}\text { Construct planning, form start and completion node time of master } \\
\text { pieces according to the requirements of processing tasks and } \\
\text { process design }\end{array}$ \\
\hline & $\begin{array}{l}\text { Resource conflict resolution } \\
\text { and plan determine }\end{array}$ & $\begin{array}{l}\text { Integrated use of all kinds of resources in production plan } \\
\text { scheduling conflict resolution theory and method, put forward } \\
\text { capability balance or logistics balance based resource conflict } \\
\text { resolution method, form the corporate level production plan }\end{array}$ \\
\hline & $\begin{array}{l}\text { Corporate level production } \\
\text { plan examination and } \\
\text { approval , delivery }\end{array}$ & $\begin{array}{c}\text { The process of approval, confirm and delivery corporate level } \\
\text { production plan }\end{array}$ \\
\hline & $\begin{array}{l}\text { Corporate level production } \\
\text { plan feedback }\end{array}$ & Plan execution feedback of actual production situation \\
\hline \multirow{2}{*}{$\begin{array}{l}\text { Workshop } \\
\text { production } \\
\text { planning } \\
\text { management }\end{array}$} & Workshop production planning & $\begin{array}{c}\text { Take MRP, TOC, JIT based corporate level production plan etc. } \\
\text { modes and methods as the preparation of workshop production } \\
\text { planning }\end{array}$ \\
\hline & $\begin{array}{l}\text { Workshop production orders } \\
\text { release }\end{array}$ & Release production orders according to workshop production plan \\
\hline \multirow{2}{*}{$\begin{array}{l}\text { Scheduling and } \\
\text { team work plan } \\
\text { management }\end{array}$} & $\begin{array}{l}\text { Scheduling parameters } \\
\text { maintenance }\end{array}$ & $\begin{array}{l}\text { Maintain production scheduling rules or scheduling parameters } \\
\text { involved in scheduling optimization algorithms }\end{array}$ \\
\hline & Scheduling rules maintenance & Establish and maintain production scheduling rules \\
\hline
\end{tabular}




\begin{tabular}{|c|c|c|}
\hline & $\begin{array}{l}\text { Scheduling model } \\
\text { maintenance }\end{array}$ & $\begin{array}{c}\text { Establish and maintain production scheduling model and } \\
\text { optimization algorithm }\end{array}$ \\
\hline & Scheduling tasks list & $\begin{array}{c}\text { Maintain scheduling tasks according to rules of production } \\
\text { scheduling constraints and station of production plan execution }\end{array}$ \\
\hline & Scheduling algorithms & Calculate scheduling tasks according to the scheduling model \\
\hline & Team plans release & $\begin{array}{l}\text { Release team task by dispatching scheme, specified machining } \\
\text { equipment, starting time of process and operation personnel } \\
\text { information, print the corresponding work ticket which used to } \\
\text { guide the workshop production and the plant processing progress } \\
\text { feedback }\end{array}$ \\
\hline & $\begin{array}{c}\text { Scheduling change } \\
\text { management }\end{array}$ & $\begin{array}{c}\text { Change and manage actual scheduling results combined with } \\
\text { enterprise production schedule }\end{array}$ \\
\hline & Scheduling tasks release & Release the final scheduling scheme as the way of scheduling tasks \\
\hline & Scheduling account & $\begin{array}{l}\text { Monitor implementation process and the result of scheduling, } \\
\text { scheduling, form a scheduling machine account }\end{array}$ \\
\hline \multirow{3}{*}{$\begin{array}{l}\text { Production } \\
\text { planning and task } \\
\text { plan control }\end{array}$} & $\begin{array}{l}\text { Workshop working hours } \\
\text { maintenance }\end{array}$ & $\begin{array}{c}\text { Set a process check on labor hours and the turnover labor hours, as } \\
\text { the foundation of operation planning, tickets release for } \\
\text { production }\end{array}$ \\
\hline & Workshop task feedback & $\begin{array}{l}\text { Workshop statistician type-in actual labor hours of per batch parts } \\
\text { machining process according to collected tickets, provide data for } \\
\text { production monitoring }\end{array}$ \\
\hline & $\begin{array}{l}\text { Task plan execution } \\
\text { monitoring }\end{array}$ & $\begin{array}{l}\text { Workshop operators processing parts according to the released } \\
\text { production work tickets, machining workshop statistician give } \\
\text { information feedback, process records, constantly monitor the } \\
\text { production status according to feedback informations }\end{array}$ \\
\hline \multirow{6}{*}{ WIP management } & Work In Process initialization & $\begin{array}{c}\text { Check WIP inventory in current products library and workshop, } \\
\text { initialization WIP initial number, similar with material balance } \\
\text { initialization }\end{array}$ \\
\hline & Workshop transfer list & $\begin{array}{c}\text { When the products/parts processing route involves many } \\
\text { departments, parts processing process need a transfer between } \\
\text { departments. Need to fill a parts list to reflect the credentials of } \\
\text { parts }\end{array}$ \\
\hline & Warehouse transfer list & $\begin{array}{l}\text { WIP warehouse keepers write warehouse transfer list according to } \\
\text { products transfer from workshop, in order to transfer to other plant } \\
\text { for processing }\end{array}$ \\
\hline & Transfer list confirmation & $\begin{array}{l}\text { Workshop planner makes transfer parts list according to } \\
\text { machining and inspection status, turnover to other processing } \\
\text { workshop or warehouse with parts, the other party planner or the } \\
\text { warehouse keeper sign the acceptance }\end{array}$ \\
\hline & WIP inquire & $\begin{array}{l}\text { Inquire the warehouse, workshop, transfer list information from } \\
\text { multiple perspectives and conditions, provide data base for } \\
\text { workshop leaders to grasp the production schedule }\end{array}$ \\
\hline & $\begin{array}{l}\text { Semi-finished products } \\
\text { warehouse application }\end{array}$ & $\begin{array}{l}\text { When parts processing completed, the workshop need to handle } \\
\text { warehousing application, fill in semi-finished products storage } \\
\text { documents }\end{array}$ \\
\hline \multirow[t]{2}{*}{$\begin{array}{l}\text { Production } \\
\text { resources } \\
\text { maintenance }\end{array}$} & Factory calendar maintenance & $\begin{array}{l}\text { Work data and work cell of each year are production informations. } \\
\text { Factory calendar module operation belongs to the basis data } \\
\text { maintenance of production management system, is the } \\
\text { precondition of all kinds of planning and capacity balance }\end{array}$ \\
\hline & Equipment resource & Data used to maintain cell production equipment and ability, and \\
\hline
\end{tabular}




\begin{tabular}{|c|c|c|}
\hline & maintenance & $\begin{array}{l}\text { defined off heavy equipment and other information on the basis of } \\
\text { production equipment }\end{array}$ \\
\hline & Labor resource maintenance & Maintain work type, qualification and ability of labor resource \\
\hline & $\begin{array}{l}\text { Work center length } \\
\text { maintenance }\end{array}$ & Refers to the length of code for work center number \\
\hline & $\begin{array}{l}\text { Work center category } \\
\text { maintenance }\end{array}$ & $\begin{array}{l}\text { The division to all sorts of work center, a collection of all kinds of } \\
\text { work center }\end{array}$ \\
\hline & $\begin{array}{l}\text { work center information } \\
\text { maintenance }\end{array}$ & $\begin{array}{l}\text { Work center is referred to various production ability, and also } \\
\text { processing costs entity. It mainly plan and control category, rather } \\
\text { than fixed assets or category of equipment management. }\end{array}$ \\
\hline \multirow{8}{*}{$\begin{array}{l}\text { System } \\
\text { maintenance }\end{array}$} & Personnel team maintenance & $\begin{array}{c}\text { For the convenience of making production operation, release and } \\
\text { print ticket, to decrease personnel selection, this system provides } \\
\text { personnel shift maintenance module to maintain data }\end{array}$ \\
\hline & WIP warehouse maintenance & $\begin{array}{l}\text { To ensure the normal management of WIP and permissions set, the } \\
\text { WIP transfer workshop and keepers have to be defined }\end{array}$ \\
\hline & System initialization & $\begin{array}{c}\text { System initialization is used to define the initial setup of operation } \\
\text { parameters, operation methods and requirements etc. of } \\
\text { production system running }\end{array}$ \\
\hline & Basic attribute category & $\begin{array}{l}\text { Need to maintain basic attribute category to ensure the normal } \\
\text { operation of production systems when officially running the } \\
\text { production system }\end{array}$ \\
\hline & Basic property maintenance & $\begin{array}{l}\text { The "essential attribute category" module data are described in } \\
\text { detail, the relations between the two is a one-to-many relationship }\end{array}$ \\
\hline & Process department reference & $\begin{array}{c}\text { Process department is to establish a process control relationship } \\
\text { with department, its data derived from the process information of } \\
\text { technology department }\end{array}$ \\
\hline & $\begin{array}{l}\text { Labor hour management } \\
\text { permissions set }\end{array}$ & $\begin{array}{l}\text { Define working hours check permissions to satisfy different } \\
\text { production department/workshop maintenance workshop labor } \\
\text { hours data }\end{array}$ \\
\hline & $\begin{array}{l}\text { Plan dispatcher permissions } \\
\text { Settings }\end{array}$ & $\begin{array}{l}\text { After production department received technical data from } \\
\text { technical department, need to prepare the production plan and } \\
\text { operation plan. In order to ensure t production plan adjustment } \\
\text { members each performs its own functions, it's necessary to make } \\
\text { individual management range of production planning and } \\
\text { scheduling according to the professional/procedures, workshop } \\
\text { distribution permissions }\end{array}$ \\
\hline
\end{tabular}

\section{Conclusion}

By constructing and running production management experiment system, reproduced the enterprise production and operation working environment tasks, processes, and work methods in a laboratory environment, and the accompanying information flow, cash flow, logistics. It's a effective method to foster economic management major students' practice ability and innovation ability, deepen the understanding of theoretical knowledge, also one of the important contents of professional education of economic management. So we take a system analysis of the complicated practical production management problem, refining out the typical problems, design experimental projects which can reflect enterprise production management functions, processes and activities. Form the entire content covering production management from management ideas to management modes to management methods. This article has carried on preliminary exploration to this problem, of course this is a new, challenging work, there are many questions we need continue to discover, analyze and solve. Guided 
by the thoughts of modern scientific management, combined with their own characteristics, embarks from the actual work, al makes this work more scientific, standardized, and get to new steps constantly.

\section{Acknowledgements}

This work was supported by Higher Education Teaching Reform Project Plans of Jiangsu Province, China (2011JSJG158).

\section{References}

[1] FENG Y, LU Z. Cultivating Innovative Talents at the University Laboratory [J][J]. Experiment Science \& Technology, 2010, 1: 061.

[2] Stefanovic M. The objectives, architectures and effects of distance learning laboratories for industrial engineering education[J]. Computers \& Education, 2013, 69: 250-262.

[3] Jiang Nayun, Fang Yexiang, FanShuHai. PBL based "operations management" course experimental teaching explore[J]. Journal of laboratory research and exploration, 2013, 32 (9).

[4] Jiang Zengqiang, E Mingcheng, Zhu Xiaomin. The study of industrial engineering experimental system[J]. Journal of laboratory research and exploration, 2013, 32 (10).

[5] Fan Shuhai, Ni Weihong, Cai Hong. Industrial engineering laboratory economical VR / 3 d reconstruction scheme[J]. Journal of laboratory research and exploration, 2011, 30 (8) : 210-212.

[6] Zhen Yuqiao, Yang ping. Applied research based industrial engineering experimental teaching method study[J]. Journal of experimental science and technology, 2013, 11 (2) : 72-73. 